\title{
Effects of Esmolol Infusion on Cardiovascular Parameters and Quality of General Anaesthesia in Younger and Older Patients
}

\author{
Dragana Lončar-Stojiljković, , 2, 3
}

\begin{abstract}
Background: Esmolol is a cardioselective $\beta$-adrenergic antagonist that is used during general anaesthesia to blunt the sympathetic reflex tachycardia and hypertension. The aim of the study was to investigate whether the potential beneficial and adverse effects of esmolol differ depending on the patient age.

Methods: A total of 50 ASA I/II patients scheduled for elective upper abdominal surgery were divided in two groups: younger (patients aged up to 35 years) and older (patients older than 65). After premedication with diazepam, they were infused with esmolol during the first $5 \mathrm{~min}$ at a rate of $0.3 \mathrm{mg} / \mathrm{kg} / \mathrm{min}$ and $0.1 \mathrm{mg} / \mathrm{kg} / \mathrm{min}$ thereafter. Anaesthesia was induced with thiopental sodium $3-5 \mathrm{mg} / \mathrm{kg}$ intravenously (iv) and fentanyl $1.5 \mu \mathrm{g} / \mathrm{kg}$ iv. Tracheal intubation was facilitated with suxamethonium 1-2 mg/kg iv. Long-term neuromuscular blockade was induced with pancuronium bromide $0.07 \mathrm{mg} / \mathrm{kg}$ iv bolus and maintained with incremental iv boluses of $0.01 \mathrm{mg} /$ $\mathrm{kg}$. Inhalational anaesthesia was maintained with a mixture of oxygen and nitrous oxide $\left(\mathrm{O}_{2} / \mathrm{N}_{2} \mathrm{O}\right) 2: 1$.

Results: The systolic blood pressure remained constant during the intubation phase in the group of older patients, at the same time being around $89 \%$ of the pre-induction values, while in younger patients it rose up to $100 \%$. During the same phase of anaesthesia, the diastolic blood pressure in older patients remained at about $91 \%$, while in younger patients it rose up to $107 \%$ of the pre-induction values. The consumption of drugs and the speed and quality of the recovery from anaesthesia did not differ between the two groups of patients.

Conclusion: Infusion of esmolol contributes to the concept of general balanced anaesthesia in elective patients scheduled for upper abdominal surgery equally in younger and older patients.
\end{abstract}

Key words: Esmolol; General balanced anaesthesia; Fentanyl; Thiopental sodium; Atropine.
(1) Faculty of Medicine, University of Banja Luka, Banja Luka, the Republic of Srpska, Bosnia and Herzegovina.

(2) Dedinje Cardiovascular Institute, Belgrade, Serbia

(3) Military Medical Academy, Belgrade, Serbia.

Correspondence: DRAGANA

LONČAR-STOJILJKOVIĆ

E: dragana.loncar-stojiljkovic@ med.unibl.org

\section{ARTICLE INFO}

Received: 20 June 2021 Revision received: 26 June 2021 Accepted: 27 June 2021

\section{Introduction}

Esmolol - methyl 3-\{4-[2-hydroxy-3-(isopropylamino)propoxy]phenyl\}propionate hydrochloride - is a selective, hydrosoluble $\beta_{1}$-adrenergic receptor blocker described first in 1982 by Zereslinski et al. ${ }^{1}$ It has a unique pharmacokinetics, since it is rapidly hydrolysed, which results in elimination half-time between 9 and 10 min..$^{2,3}$ It was demonstrated that the esterase responsible for such a rapid hydrolysis of esmolol is located in the cytosol of human erythrocytes. ${ }^{4}$ These properties of esmolol make it easily titratable, which enables a perfect control of the degree of $\beta$-blockade, in con- 
trast to the undesirable effects of the intravenous (iv) preparations of propranolol and metoprolol. ${ }^{5}$

Esmolol has a 34-fold higher affinity for $\beta_{1}$ - in comparison with $\beta_{2}$-adrenoceptors. ${ }^{6}$ For this reason, it was first approved for treatment of supraventricular tachyarrhythmias. ${ }^{7}$ Later adopted indications include: hypertension and tachycardia following tracheal intubation and other critical phases of anaesthesia and operation in non-cardi$\mathrm{ac}^{8,9,10}$ and cardiac surgery, ${ }^{11,12}$ but also in non-surgical indications, such as electroconvulsive therapy, ${ }^{13}$ thyrotoxic storm ${ }^{14-17}$ and treatment of septic patients. ${ }^{18-20}$

It is now well-stablished that esmolol alleviates a reflex hypertension and tachycardia that occur due to extremely painful stimuli that accompany some critical phases of anaesthesia and operation, contributing thus to the concept of general balanced anaesthesia. ${ }^{21,22}$ At the same time, blood pressure in humans increases in a linear manner with age, ${ }^{23,24}$ as well as the prevalence of bradycardia. ${ }^{25}$ Given the mechanism of action of esmolol, the question arises whether the efficacy and safety of esmolol infusions during the perioperative period can bring different beneficial and adverse effects in older patients, in comparison with the younger ones. This was the aim of the present study.

\section{Methods}

A total of 50 patients scheduled for upper abdominal elective surgery at the Military Medical Academy was enrolled in this clinical trial. It was approved by the local Ethics Committee. They had to be $\geq 18$ of age and without any significant cardiovascular and metabolic morbidities (acute coronary disease, past myocardial infarction, transient ischaemic attack or stroke, diabetes) and of ASA I or II grade. Patients older than 35 but younger than 65 were excluded. In this way, two groups were formed - the younger $(\mathrm{N}=26)$ and the older patient group $(\mathrm{N}=24)$.

All patients received prior to induction of anaesthesia an iv infusion of esmolol in glucose solution $5 \%$, during the first $5 \mathrm{~min}$ at a rate of $0.3 \mathrm{mg} / \mathrm{kg} /$ min and $0.1 \mathrm{mg} / \mathrm{kg} / \mathrm{min}$ thereafter. This maintenance infusion rate was selected based on the notion that hypotension rarely occurred when the esmolol infusion rate was below $0.15 \mathrm{mg} / \mathrm{kg} /$ $\min ^{26}$

All patients received the same type of anaesthesia. Premedication consisted of diazepam $10 \mathrm{mg}$ intramuscularly (im), administered 30-45 min before anaesthesia. Anaesthesia was induced with thiopental sodium 3-5 mg/kg iv and fentanyl 1.5 $\mu \mathrm{g} / \mathrm{kg}$ iv. Tracheal intubation was facilitated with suxamethonium 1-2 mg/kg iv. Long-term neuromuscular blockade was induced by pancuronium bromide $0.07 \mathrm{mg} / \mathrm{kg}$ iv bolus, while the desirable level of neuromuscular relaxation was maintained by its incremental iv boluses of $0.01 \mathrm{mg} / \mathrm{kg}$. Inhalational anaesthesia was maintained with a mixture of oxygen and nitrous oxide $\left(\mathrm{O}_{2} / \mathrm{N}_{2} \mathrm{O}\right)=2: 1$.

Episodes of increase of systolic and diastolic blood pressure and heart rate by more than 20 $\%$ of its pre-induction values were treated with iv boluses of fentanyl $1.5 \mu \mathrm{g} / \mathrm{kg}$ alone or in combination with droperidol 1:50 (Thalamonal ${ }^{\circledR}$ ). In case of unfavourable response, isoflurane $0.5 \%$ was added as an inhalation. Upon completion of the operation, atropine $0.5 \mathrm{mg}$ iv was injected and the residual neuromuscular block was antagonised with neostigmine $1.5 \mathrm{mg}$ iv. The same dose of atropine was used as an iv bolus during the operation in case of bradycardia, which was defined as a decrease of heart rate below $60 / \mathrm{min}$ or by more than $20 \%$ of the pre-induction values. ${ }^{25}$

Registration of all major cardiovascular parameters - systolic and diastolic blood pressure and heart rate was performed in critical phases of anaesthesia and intubation: (1) before the induction (baseline), (2) induction to anaesthesia, (3) tracheal intubation, (4) first skin incision, (5) surgical manipulation with organs, (6) suture of the surgical wound and (7) tracheal extubation. Besides, total consumption of fentanyl, droperidol, atropine, pancuronium and isoflurane was registered. Quality of the post-anaesthesia recovery was based on the registration of times needed to regain ability to comply with simple commands (eg, eye opening), to open eyes spontaneously and until regaining full orientation. Adverse effects were registered and scored: 1 - mild, 2 - moderate and 3 - strong. Overall assessment of the quality of anaesthesia was performed by the experienced anaesthesiologist, by using the scale: 1 - poor, 2 good and 3 - excellent.

Statistical analysis was performed by using para- 
metric or non/parametric tests, depending on the nature of the parameters observed and the normality of their distribution. IBM SPSS 18.0 software was used for these analyses.

\section{Results}

Based on Table 1, it is obvious that other the age difference - the younger patient group was on average 2.36 times younger than the older group - there were no demographic criteria that made these two groups different from one another. However, as a direct consequence of this age difference, the pre-induction values of all three cardiovascular parameters differed significantly. Systolic and diastolic blood pressure were by $25 \%$ and $19 \%$ higher, while the heart rate was by $14 \%$ lower in elderly patients.

Table 1: Demographic data and preinduction values of the cardiovascular parameters in younger and elderly patients scheduled to receive esmolol during the operation under the general balanced anaesthesia

\begin{tabular}{lccc}
\hline $\begin{array}{l}\text { Parameter } \\
\text { (unit) }\end{array}$ & $\begin{array}{c}\text { Younger patients } \\
(\mathbf{x} \pm \text { SE) }\end{array}$ & $\begin{array}{c}\text { Older patients } \\
(\mathbf{x} \pm \text { SE) }\end{array}$ & $\begin{array}{c}\text { Statistical } \\
\text { significance }\end{array}$ \\
\hline Age (years) & $29.23 \pm 78.46$ & $68.85 \pm 1.24$ & $\mathrm{p}<0.01$ \\
\hdashline Body weight (kg) & $78.46 \pm 3.80$ & $74.69 \pm 2.70$ & $\mathrm{~ns}$ \\
\hline Gender: male/female & 12 vs 1 & 9 vs 4 & $\mathrm{~ns}$ \\
\hline Systolic blood pressure & $135.54 \pm 6.52$ & $168.85 \pm 7.30$ & $\mathrm{p}<0.01$ \\
\hline Diastolic blood pressure & $84.08 \pm 13.02$ & $100.39 \pm 3.32$ & $\mathrm{p}<0.05$ \\
\hline Heart rate & $107.31 \pm 11.55$ & $92.15 \pm 4.47$ & $\mathrm{p}<0.01$ \\
\hline
\end{tabular}

*Younger patients: patients 18-35 years of age, $N=26$; Older patients: patients older than $65, N=24 ; n s$ - not significant;

Figures 1, 2 and 3 show changes in basic cardiovascular parameters in all the critical phases of anaesthesia and surgery. It is obvious that esmolol in both groups assured good control of cardiovascular parameters, but also that there were some differences between the groups.

The systolic blood pressure remained constant during the intubation phase in the group of older patients, at the same time being around $89 \%$ of the pre-induction values, while in younger patients it rose up to $100 \%$ (Figure 1). During the same phase of anaesthesia, the diastolic blood pressure in older patients remained at about 91 $\%$, while in younger patients it rose up to $107 \%$ of the pre-induction values. The same phenomenon occurred also during the phases of the first skin incision and surgical manipulations with organs (Figure 2). It is interesting though that among the two age groups there were no statistically signif-

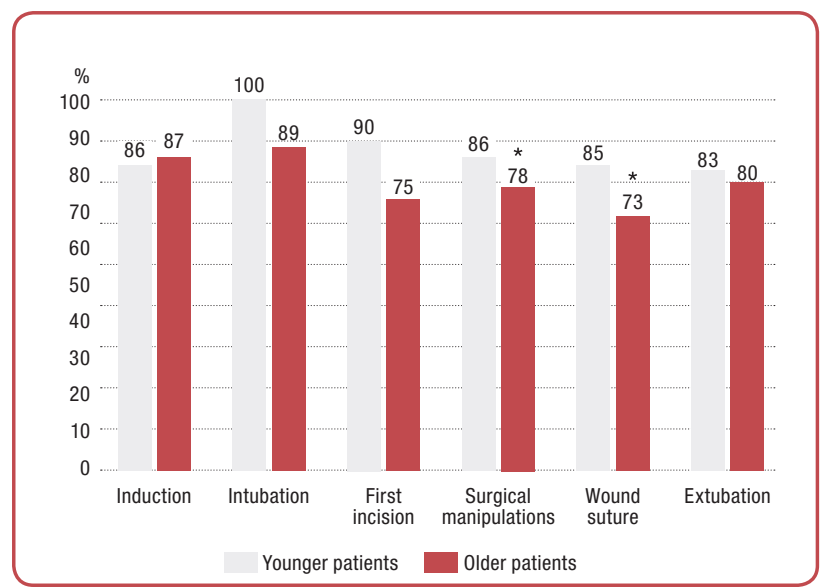

Figure 1: Systolic blood pressure in various phases of anaesthesia and operation in patients infused with esmolol

\%: Values are expressed as percentages of pre-induction values; Younger patients: patients 18-35 years of age, $N=26$; Older patients: patients older than $65, N=24 ; *$ : statistical significance;

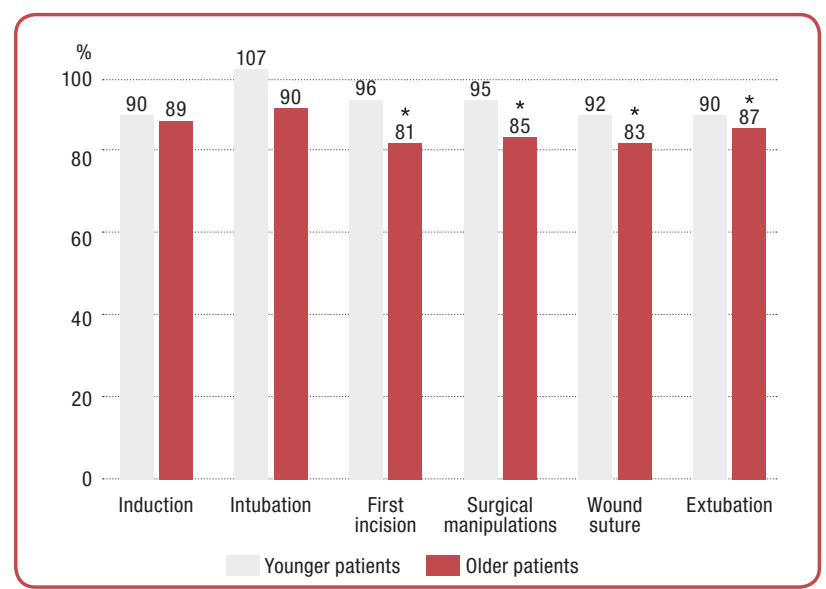

Figure 2: Diastolic blood pressure in various phases of anaesthesia and operation in patients infused with esmolol

$\%$ : Values are expressed as percentages of pre-induction values; Younger patients: patients 18-35 years of age, $N=26$; Older patients: patients older than $65, N=24 ; *$ : statistical significance;

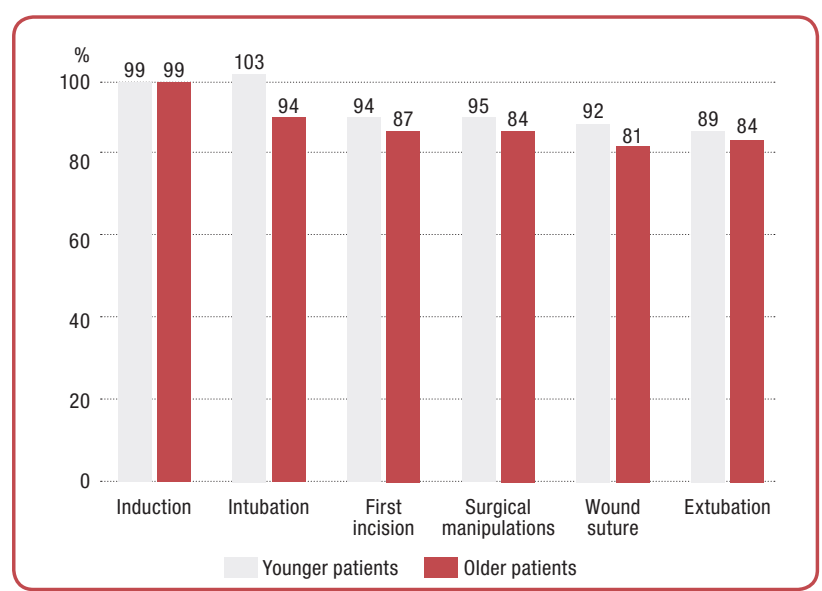

Figure 3: Heart rate in various phases of anaesthesia and operation in patients infused with esmolol

\%: Values are expressed as percentages of pre-induction values; Younger patients: patients 18-35 years of age, $N=26$; Older patients: patients older than $65, N=24$; *: statistical significance; 
icant differences between the values of heart rate during the critical phases of anaesthesia and operation (Figure 3).

At the same time, the consumption of anaesthetic drugs fentanyl, droperidol, atropine and isoflurane was similar in both groups (Table 2).

Table 2: Consumption of medicines in younger and elderly patients scheduled to receive esmolol during the operation under the general balanced anaesthesia

\begin{tabular}{lccc}
\hline Drug (unit) & $\begin{array}{c}\text { Younger patients } \\
(\mathbf{x} \pm \mathbf{S E})\end{array}$ & $\begin{array}{c}\text { Older patients } \\
(\mathbf{x} \pm \mathbf{S E})\end{array}$ & $\begin{array}{c}\text { Statistical } \\
\text { significance }\end{array}$ \\
\hline Fentanyl $(\mathrm{mg})$ & $0.38 \pm 0.88$ & $0.30 \pm 0.66$ & $\mathrm{~ns}$ \\
\hdashline Droperidol $(\mathrm{mg})$ & $6.11 \pm 1.48$ & $5.15 \pm 1.93$ & $\mathrm{~ns}$ \\
\hline Atropine $(\mathrm{mg})$ & $1.02 \pm 0.09$ & $0.91 \pm 0.07$ & $\mathrm{~ns}$ \\
\hline Pancuronium $(\mathrm{mg})$ & $5.98 \pm 0.44$ & $5.22 \pm 0.34$ & $\mathrm{~ns}$ \\
\hline Isoflurane $(\%$ of patients) & 15.39 & 12.50 & $\mathrm{~ns}$ \\
\hline
\end{tabular}

Younger patients: patients 18-35 years of age, $N=26$; Older patients: patients older than $65, N=24 ; n s$ - not significant;

Table 3: Effect of esmolol on speed and quality of postoperative recovery in younger and elderly patients scheduled to receive esmolol during the operation under the general balanced anaesthesia

\begin{tabular}{lccc}
\hline $\begin{array}{l}\text { Parameter } \\
\text { (unit) }\end{array}$ & $\begin{array}{c}\text { Younger patients } \\
(\mathbf{x} \pm \mathbf{S E})\end{array}$ & $\begin{array}{c}\text { Older patients } \\
(\mathbf{x} \pm \mathbf{S E})\end{array}$ & $\begin{array}{c}\text { Statistical } \\
\text { significance }\end{array}$ \\
\hline $\begin{array}{l}\text { Duration of anaesthesia } \\
\text { (min) }\end{array}$ & $108.54 \pm 8.97$ & $120.54 \pm 11.34$ & $\mathrm{~ns}$ \\
\hline $\begin{array}{l}\text { Opening of eyes on } \\
\text { command (min) }\end{array}$ & $2.94 \pm 0.44$ & $3.02 \pm 0.12$ & $\mathrm{~ns}$ \\
\hline $\begin{array}{l}\text { Spontaneous opening of } \\
\text { eyes (min) }\end{array}$ & $5.23 \pm 0.49$ & $6.20 \pm 0.55$ & $\mathrm{~ns}$ \\
\hline \begin{tabular}{l} 
Full orientation (min) \\
\hdashline
\end{tabular} & $8.44 \pm 0.95$ & $9.00 \pm 1.20$ & $\mathrm{~ns}$ \\
\hline $\begin{array}{l}\text { Extubation possible } \\
\text { (\% of patients) }\end{array}$ & 96.15 & 87.50 & $\mathrm{~ns}$ \\
\hline $\begin{array}{l}\text { Evaluation of quality of } \\
\text { anaesthesia* }\end{array}$ & $2.70 \pm 0.13$ & $2.22 \pm 0.11$ & $\mathrm{~ns}$ \\
\hline
\end{tabular}

Younger patients: patients 18-35 years of age, $N=26$; Older patients: patients older than 65, N = 24; ns - not significant; Scale: 1 - poor, 2 - good, 3 - excellent;

Table 4: Frequency of adverse effects in younger and older patients scheduled to receive esmolol during the operation under the general balanced anaesthesia

\begin{tabular}{lccc}
\hline Adverse effect & $\begin{array}{c}\text { Younger patients } \\
\text { Number (\%) }\end{array}$ & $\begin{array}{c}\text { Older patients } \\
\text { Number (\%) }\end{array}$ & $\begin{array}{c}\text { Statistical } \\
\text { significance }\end{array}$ \\
\hline Ventricular extrasystoles & $2(7.69)$ & $2(8.33)$ & ns \\
\hline Tachycardia & $1(3.85)$ & 0 & ns \\
\hdashline Bradycardia & 0 & $2(8.33)$ & ns \\
\hdashline Hypotension & $1(3.85)$ & $2(8.33)$ & ns \\
\hline Skin rash & $1(3.85)$ & 0 & ns \\
\hline Total & $5(19.23)$ & $6(25)$ & ns \\
\hline
\end{tabular}

Younger patients: patients $18-35$ years of age, $N=26$; Older patients: patients older than $65, N=24 ; n s$ : not significant;

Moreover, as seen in Table 3, no significant difference between the younger and older group of patients could be found regarding the speed of their recovery, possibilities for early extubation or in the subjective anaesthesiological assessment of the quality of anaesthesia in general.
Frequency of adverse effects in younger and older patients is shown in Table 4. Although there was a tendency toward more frequent occurrence of bradycardia and hypotension in the group of older patient, neither of these differences were significant.

\section{Discussion}

This clinical study has shown that there were no major differences in the change of cardiovascular parameters, consumption of drugs nor in the quality of the recovery from the balanced endotracheal anaesthesia in elective upper abdominal surgery patients infused with esmolol between the groups of younger and older patients. Since the baseline values of cardiovascular parameters were different - higher blood pressure and lower heart rate in older than in younger patients - these changes were expressed as percentages of the pre-induction values and not in absolute units.

Stability of cardiovascular function is one of the main goals in the concept of general balanced anaesthesia. $^{27,28}$ This is why esmolol was viewed as an additional component within thus concept - a so-called 'soft' $\beta$-blocker for administration as an iv bolus or iv infusion with a rapid kinetics that allows for its titration to the needs of a specific patient and the particular phase of anaesthesia and operation..$^{29-31}$ The contribution of esmolol to the concept consists in the decrease in the doses of or the need for administration of intravenous anaesthetics, ${ }^{32}$ inhalation anaesthetics, ${ }^{32,33}$ opioid analgesics ${ }^{34}$ and even neuromuscular relaxants. ${ }^{35}$

There are no available publications on the differences in potential beneficial and adverse effects of esmolol regarding the age of the patients. What could be expected is that esmolol induces a sharper decrease of the already higher values of systolic and diastolic blood pressure and especially in the heart rate in the group of older patients, as compared to the younger ones. Besides, it was to be expected that esmolol is less efficient in coping with the increases in blood pressure in the older group, but neither of these happened, nor this group required higher doses of fentanyl or atropine to treat the episodes of bradycardia.

There are only two studies that focused on the desired and unwanted effects of esmolol in older patients, but neither of them included for comparison a group of younger patients. In a randomised 
clinical trial in 27 patients scheduled for short eye surgery, aged $76 \pm 7$, half of the patients received a bolus of esmolol 2 or $3 \mathrm{mg} / \mathrm{kg}$, while the rest of them were treated with local anaesthetic administration. ${ }^{36}$ The goal of this study was to compare the cardiovascular effects of these two procedures. Although the type of general anaesthesia was similar to the one used in the present study, the authors administered esmolol in the form of the iv bolus, in contrast with the iv infusion, used in this study. Out of five patients treated with higher dose of esmolol - $3 \mathrm{mg} / \mathrm{kg}$ - four experienced a significant hypotension and one of these four had a vascular collapse. The regime of esmolol utilised in the present study was obviously less drastic - first, during $5 \mathrm{~min}$, an infusion at a rate of during the first $5 \mathrm{~min}$ at a rate of 0.3 $\mathrm{mg} / \mathrm{kg} / \mathrm{min}$ and $0.1 \mathrm{mg} / \mathrm{kg} / \mathrm{min}$ thereafter and was followed by a much more favourable cardiovascular response.

In another open clinical trial in 22 elderly patients scheduled for cataract surgery, half was treated with esmolol and the other half with labetalol. ${ }^{37}$ The esmolol group was aged $78 \pm 9$ and all of them had extremely high perioperative blood pressure values - systolic pressure $>200$ $\mathrm{mmHg}$ diastolic pressure $>100 \mathrm{mmHg}$, as defined by the inclusion criteria. The dosage regimen in this study was much more similar to the one in the present study - esmolol was administered in a small iv bolus of $0.5 \mathrm{mg} / \mathrm{kg}$, followed by the iv infusion at a rate of $0.15-0.30 \mathrm{mg} / \mathrm{kg} / \mathrm{min}$. Although the therapeutic goal was assured - systolic blood pressure reduction by $20 \%$ (from $217 \pm 12.3$ $\mathrm{mmHg}$ to $175 \pm 4.0 \mathrm{mmHg}$ ), the level of heart rate reduction was moderate (from $81 \pm 9$ to $61 \pm 8$ / min). Two out of 11 patients treated with esmolol developed a serious bradycardia (heart rate $<50$ / min) and for them esmolol was discontinued. In the present study, bradycardia was defined as heart rate $<60 / \mathrm{min}$ and it was registered in two out of 24 patients. This difference could be explained by a significantly higher age of the patients in the study published by Singh and co-workers. ${ }^{37}$

\section{Conclusion}

Infusion of esmolol contributes to the concept of general balanced anaesthesia in elective patients scheduled for upper abdominal surgery equally in younger (aged 18-35) and older patients (aged 65 or more). In both groups, esmolol assured perioperative cardiovascular stability, good recovery after anaesthesia and favourable profile of adverse effects.

\section{References}

1. Zaroslinski J, Borgman RJ, O’Donnell JP, Anderson WG, Erhardt PW, Kam ST, et al. Ultra-short acting beta-blockers: a proposal for the treatment of the critically ill patient. Life Sci 1982 Aug 30;31(9):899-907.

2. Sum CY, Yacobi A, Kartzinel R, Stampfli H, Davis CS, Lai CM. Kinetics of esmolol, an ultrashort-acting beta blocker, and of its major metabolite. Clin Pharmacol Ther 1983 Oct;34(4):427-34.

3. De Bruijn NP, Reves JG, Croughwell N, Clements F, Drissel DA. Pharmacokinetics of esmolol in anesthetized patients receiving chronic beta blocker therapy. Anesthesiology 1987 Mar;66(3):323-6.

4. Quon CY, Mai K, Patil G, Stampfli HF. Species differences in the stereoselective hydrolysis of esmolol by blood esterases. Drug Metab Dispos 1988 May;16(3):425-8.

\section{Acknowledgements}

None.

\section{Conflict of interest}

None.
5. Reilly CS, Wood M, Koshakji RP, Wood AJ. Ultra-short-acting beta-blockade: a comparison with conventional beta-blockade. Clin Pharmacol Ther 1985 Nov;38(5):579-85.

6. Jahn P, Eckrich B, Schneidrowski B, Volz-Zang C, Schulte B, Mutschler E, et al. Beta 1-adrenoceptor subtype selective antagonism of esmolol and its major metabolite in vitro and in man. Investigations using tricresylphosphate as red blood cell inhibitor. Arzneimittelforschung 1995 May;45(5):536-41.

7. Anderson S, Blanski L, Byrd RC, Das G, Engler R, Laddu A, et al. Comparison of the efficacy and safety of esmolol, a short-acting beta blocker, with placebo in the treatment of supraventricular tachyarrhythmias. The Esmolol vs Placebo Multicenter Study Group. Am Heart J 1986 Jan;111(1):42-8. 
8. Capuzzo M, Verri M, Alvisi R. Hemodynamic responses to laryngoscopy and intubation: etiological or symptomatic prevention? Minerva Anestesiol 2010 Mar;76(3):173-4.

9. Guney A, Kaya FN, Yavascaoglu B, Gurbet A, Selmi NH, Kaya S, et al. Comparison of esmolol to nitroglycerine in controlling hypotension during nasal surgery. Eurasian J Med 2012 Aug;44(2):99-105.

10. Bajracharya JL, Subedi A, Pokharel K, Bhattarai B. The effect of intraoperative lidocaine versus esmolol infusion on postoperative analgesia in laparoscopic cholecystectomy: a randomized clinical trial. BMC Anesthesiol 2019;19:198. doi: 10.1186/s12871-019-0874-8.

11. Girard D, Shulman BJ, Thys DM, Mindich BP, Mikula SK, Kaplan JA. The safety and efficacy of esmolol during myocardial revascularization. Anesthesiology 1986 Aug;65(2):157-64.

12. Efe EM, Bilgin BA, Alanoglu Z, Akbaba M, Denker C. Comparison of bolus and continuous infusion of esmolol on hemodynamic response to laryngoscopy, endotracheal intubation and sternotomy in coronary artery bypass graft. Rev Bras Anestesiol 2014 Jul-Aug;64(4):247-52.

13. Parikh DA, Garg SN, Dalvi NP, Surana PP, Sannakki D, Tendolkar BA. Outcome of four pretreatment regimes on hemodynamics during electroconvulsive therapy: a double-blind randomized controlled crossover trial. Ann Card Anaesth 2017 Jan-Mar;20(1):93-9.

14. Pemberton P, Veenith T, Snelson C, Whitehouse T. Is it time to beta block the septic patient? Biomed Res Int 2015;2015:424308. doi: 10.1155/2015/424308.

15. Vijayakumar HR, Thomas WO, Ferrara JJ. Peri-operative management of severe thyrotoxicosis with esmolol. Anaesthesia 1989 May;44(5):406-8.

16. Isley WL, Dahl S, Gibbs H. Use of esmolol in managing a thyrotoxic patient needing emergency surgery. Am J Med 1990 Jul;89(1):122-3.

17. Knighton JD, Crosse MM. Anaesthetic management of childhood thyrotoxicosis and the use of esmolol. Anaesthesia 1997 Jan;52(1):67-70.

18. Duggal J, Singh S, Kuchinic P, Butler P, Arora R. Utility of esmolol in thyroid crisis. Can J Clin Pharmacol 2006 Fall;13(3):e292-5.

19. Morelli A, Sanfilippo F, Romano SM. Esmolol in septic shock: old pathophysiological concept, an old drug, perhaps a new hemodynamic strategy in the right patient. J Thorac Dis 2016 Nov;8(11):3059-62.

20. Brown SM, Beesley SJ, Lanspa MJ, Grissom CK, Wilson EL, Parikh SM, et al. Esmolol infusion in patients with septic shock and tachycardia: a prospective, single-arm, feasibility study. Pilot Feasibility Stud 2018 Aug 3;4:132. doi: 10.1186/s40814-018-0321-5.

21. Stojiljković MP, Dobrić S, Lončar-Stojiljković D, Marenović T, Bošković B. [Use of esmolol in treatment of perioperative tachycardia and hypertension]. Pharmaca Iugoslav 1994;32(1):5-8. Serbian.

22. Lončar-Stojiljković D, Dobrić S, Stojiljković MP, Marenović T, Bošković B. [Esmolol as an adjunct to neurosurgical anaesthesia]. Arh Farm 1994;44(1-2):270-1. Serbian.

23. NCD Risk Factor Collaboration (NCD-RisC). Long-term and recent trends in hypertension awareness, treatment, and control in 12 high-income countries: an analysis of 123 nationally representative surveys. Lancet 2019 Aug 24;394(10199):639-51.

24. Survila K, Lengen V, Cheng S, Niiranen TJ. Age of hypertension onset: overview of research and how to apply in practice. Curr Hypertens Rep 2020 Aug 27;22(9):68. doi: 10.1007/s11906-020-01071-z.

25. Lin PH, Zhou W, Kougias P, El Sayed HF, Barshes NR, Huyinh TT. Factors associated with hypotension and bradycardia after carotid angioplasty and stenting. J Vasc Surg 2007 Nov;46(5):846-53.

26. Wiest D. Esmolol. A review of its therapeutic efficacy and pharmacokinetic characteristics. Clin Pharmacokinet 1995 Mar;28(3):190-202.

27. Gerges FJ, Kanazi GE, Jabbour-Khoury SI. Anesthesia for laparoscopy: a review. J Clin Anesth 2006 Feb;18(1):67-78.

28. Vos JJ, Poterman M, Hannivoort LN, Renardel De Lavalette VW, Struys MM, Scheeren TW, et al. Hemodynamics and tissue oxygenation during balanced anesthesia with a high antinociceptive contribution: an observational study. Perioper Med (Lond) 2014 Oct 30;3:9. doi: 10.1186/20470525-3-9.

29. Vucevic M, Purdy GM, Ellis FR. Esmolol hydrochloride for management of the cardiovascular stress responses to laryngoscopy and tracheal intubation. Br J Anaesth 1992 May;68(5):529-30.

30. Wilson ES, McKinlay S, Crawford JM, Robb HM. The influence of esmolol on the dose of propofol required for induction of anaesthesia. Anaesthesia 2004 Feb;59(2):122-6.

31. Kang KJ, Yoo SH, Chung JH, Kim NS, Jung HS, Seo YH, et al. Dosing study of esmolol for reducing hemodynamic changes during lightwand intubation. Anesth Pain Med (Seoul) 2020 Oct 30;15(4):417-23.

32. Asouhidou I, Trikoupi A. Esmolol reduces anesthetic requirements thereby facilitating early extubation; a prospective controlled study in patients undergoing intracranial surgery. BMC Anesthesiol 2015 Nov 28;15:172. doi: 10.1186/s12871-015-0154-1.

33. Johansen JW, Flaishon R, Sebel PS. Esmolol reduces anesthetic requirement for skin incision during propofol/ nitrous oxide/morphine anesthesia. Anesthesiology 1997 Feb;86(2):364-71.

34. Dhir R, Singh MR, Kaul TK, Tewari A, Oberoi R. Effect of intravenous esmolol on analgesic requirements in laparoscopic cholecystectomy. J Anaesthesiol Clin Pharmacol 2015 Jul-Sep;31(3):375-9.

35. Ergil J, Kavak Akelma F, Özkan D, Bumin Aydin G, Gürel A, Akinci M. Effects of pretreatment with esmolol and lidocaine on injection pain and rocuronium-induced withdrawal response. Turk J Med Sci 2015;45(4):959-63.

36. Mion G, Ruttimann M, Descraques C, Chabanne JP. [Bolus esmolol prior to tracheal intubation of the elderly patient]. Cah Anesthesiol 1992;40(2):95-9. French.

37. Singh PP, Dimich I, Sampson I, Sonnenklar N. A comparison of esmolol and labetalol for the treatment of perioperative hypertension in geriatric ambulatory surgical patients. Can J Anaesth 1992 Jul;39(6):559-62. 